\title{
Ecological, Biological and Hematological Index of the Blood Analysis of Sturgeons (Acipenser) in the Caspian Sea
}

\section{Naid Abdulaeva and Saniyat Alieva}

Dagestan State University Makhachkala, Russia

ORCID:

Saniyat Alieva: http://orcid.org/0000-0002-3794-1539

\section{Abstract}

The Caspian is a unique drainless water body with no connection to the ocean. This study of the peculiarities of blood cell composition of the Russian sturgeon (Acipenser güldenstädtii) and sevruga (Acipenser stellatus) revealed minor destructive disorders of the blood cells. The number of blood cells also deviated from conditional norms. The study of the leukocyte profile of sturgeons showed the granular forms of leukocytes, band neutrophils and eosinophils, and segmentonuclear neutrophils and

Corresponding Author:

Naid Abdulaeva

caca1@yandex.ru

Published: 5 April 2021

Publishing services provided by Knowledge E

(c) Naid Abdulaeva and Saniyat Alieva. This article is distributed under the terms of the

Commons Attribution License, which permits unrestricted use and redistribution provided that the original author and source are credited.

Selection and Peer-review under the responsibility of the DonAgro Conference Committee.

\section{G OPEN ACCESS} eosinophils. The total number of granulocytes in the blood of the Russian sturgeon was increased, which indicated the activation of the body's protective systems in response to the anthropogenic load. In cytomorphological terms, the destructive disorders were revealed. Such phenomena are associated with the ever-increasing anthropogenic load on the biocenoses of natural reservoirs. Summarizing the results, it can be concluded that the quantitative indicators of red blood in the Russian sturgeon (Acipenser gueldenstaedtii) and sevruga (Acipenser stellatus) caught off of the Dagestan coast of the Caspian Sea were reduced in the spring of 2018 compared to 2016, but were in the normal range given in the literature. The concentration of hemoglobin in the Russian sturgeon and sevruga in 2016 was 13\% and 15\% higher than in 2014, respectively. This phenomenon could be a measure to compensate for the lack of oxygen in various fish tissues and organs.

Keywords: Russian sturgeon, red blood cells, lymphocytes, eosinophils, neutrophils, anisocytosis, cytolysis of red blood cells.

\section{Introduction}

The study of ecological, physiological and biochemical mechanisms of fish adaptation to changing habitat conditions becomes particularly relevant due to increased anthropogenic interference in the natural ecosystems [1]

One of the key parameters of the Caspian waters is the content of dissolved oxygen $\left(\mathrm{O}_{2}, \mathrm{ml} / \mathrm{l}\right)$, since it is this value, and not slightly vertically changing salinity, that is most significant for peculiar southern waters. The saturation of coastal waters with oxygen in 
2018 ranged from 6.10 to $7.50 \mathrm{mg} / \mathrm{l}$ and corresponded to the norm, i.e. it was favorable for hydrobionts.

The nitrate content in the waters of the coastal part of the Caspian during the year amounted to $0.48-0.70 \mathrm{mg} / \mathrm{l}$, with an average annual value of $0.61 \mathrm{mg} / \mathrm{l}$, which is insignificant, but higher than the same value last year $-0.57 \mathrm{mg} / \mathrm{l}$.

Nitrites in seawater were found seasonally at concentrations of $0.028-0.064 \mathrm{mg} / \mathrm{l}$, with a maximum in the autumn period. The average annual value was $0.044 \mathrm{mg} / \mathrm{l}$, which is slightly lower than last year $(0.048 \mathrm{mg} / \mathrm{l})$.

All these factors create the "extremality" of habitat conditions for fish and negatively affect their physiological state thus disrupting the metabolism and functioning of vital systems [1, 2]

The study of ecological-biological and cytomorphological blood values of valuable sturgeon fish is necessary for more complete and comprehensive functional characteristic of homeostasis in relation to their adaptation capabilities [3]

To study the hematological indicators (quantitative and cytomorphological) of sturgeon fish using the example of the Russian sturgeon (Acipenser gueldenstaedtii) and sevruga (Acipenser stellatus) living in the Middle Caspian Sea over 2016-2018.

\section{Methods and materials}

The material of the study was sturgeon: Russian sturgeon (Acipenser gueldenstaedtii) and sevruga (Acipenser stellatus) caught of the Dagestan coast of the Caspian Sea in the spring period 2016-2018 at the age of $1-2$ years, weight $-1.2-2.4 \mathrm{~kg}$, length $-35-80$ $\mathrm{cm}$. The total number of fish was 10 specimens of each species in 2016 and 2018.

The Goryaev chamber was used to calculate the total number of blood corpuscles. Red blood cells were counted in five large squares: in four squares, located at the corners, and in one located in the center of the grid, i.e. in 80 small squares. All cells lying not only inside the square itself, but also on its border lines were considered, and the majority of the cells fell on the inside of the part of the square. The average number of cells was determined by dividing all counted cells by the number of squares in which the blood corpuscles were counted. The resulting figure was the average number of cells contained in $1 / 4000 \mathrm{~mm}^{3}$. The average of $1 \mathrm{~mm}^{3}$ of blood corpuscles was obtained by multiplying the result by 4000 and the dilution ratio.

To establish leukocytes in $1 \mathrm{~mm}^{3}$ in different areas of the Goryaev chamber, 25 large squares were counted at two opposite corners of the grid. The obtained number of 
white blood cells in 50 large squares, i.e. in 800 small squares, was substituted into the formula

$*=(X 400020) / 800$, and an average of $10^{3} \mu$ l of blood corpuscles was obtained.

To determine the amount of hemoglobin, $5 \mathrm{ml}$ of transformer and $20 \mu \mathrm{l}$ of blood were mixed. After 10 minutes, hemoglobin was determined on a MiniGEM-540 apparatus and expressed as $\mathrm{g} / \mathrm{l}$.

To determine the leukocyte formula, 200 white blood cells in a smear were counted. All white blood cells were recorded in a special table according to the classification of cell forms and the percentage of white blood cells was counted, i.e. groups of white blood cells in percent [4]

The obtained results were subjected to statistical analysis using the Statistica-12 data processing package. The differences were considered valid at $p<0.05$.

\section{Results}

It is known that blood is a sensitive and informative indicator of the state of the body, quickly responding to changes of exogenous and endogenous factors. The dynamics of hematological indicators can serve as a marker of the state of the fish body in natural reservoirs $[1,5,6]$ We studied the changes in blood values of the Russian sturgeon and sevruga caught of the Dagestan coast of the Caspian Sea in the spring period 20162018 (Table 1). According to data obtained in the spring of 2014 , the number of red blood cells in the blood of the Russian sturgeon was $0.5 \times 10^{6} / \mu \mathrm{l}$, sevruga $-0.68 \times 10^{6} / \mu \mathrm{l}$, which corresponds to the literary data $-0.4 \times 10^{6} / \mu \mathrm{l}-0.70 \times 10^{6} / \mu \mathrm{l}$ [7] One important indicator of red blood is hemoglobin. On average, its concentration in the Russian sturgeon was at the level of $160 \mathrm{~g} / \mathrm{l}$, in sevruga - $120 \mathrm{~g} / \mathrm{l}$. The obtained data exceed the relatively conventional norm specified in the literature $(83-92 \mathrm{~g} / \mathrm{l})$.

The cytomorphological study of blood smears of the Russian sturgeon and sevruga revealed that red blood cells had a rounded, oval shape. Cell nuclei were rounded in shape with well-visible chromatin. They were dyed blue using azure-eosin. There were red blood cells with wall nuclei. Besides, anucleate red cells were detected in the peripheral blood of the studied fish, but their contours were preserved. The characteristic pathological changes in the structure of red blood cells found through the morphological analysis included anisocytosis (size variation) and cytolysis (destruction) of red blood cells (Fig. 1).

The white blood of the tested fish revealed that the average total white blood cell content in the Russian sturgeon was $14.4 \times 10^{3} / \mu$, which is slightly lower than the 
TABLE 1: Hematological indicators of sturgeon fish (Acipenser) caught of the Dagestan coast of the Caspian Sea (2016-2018).

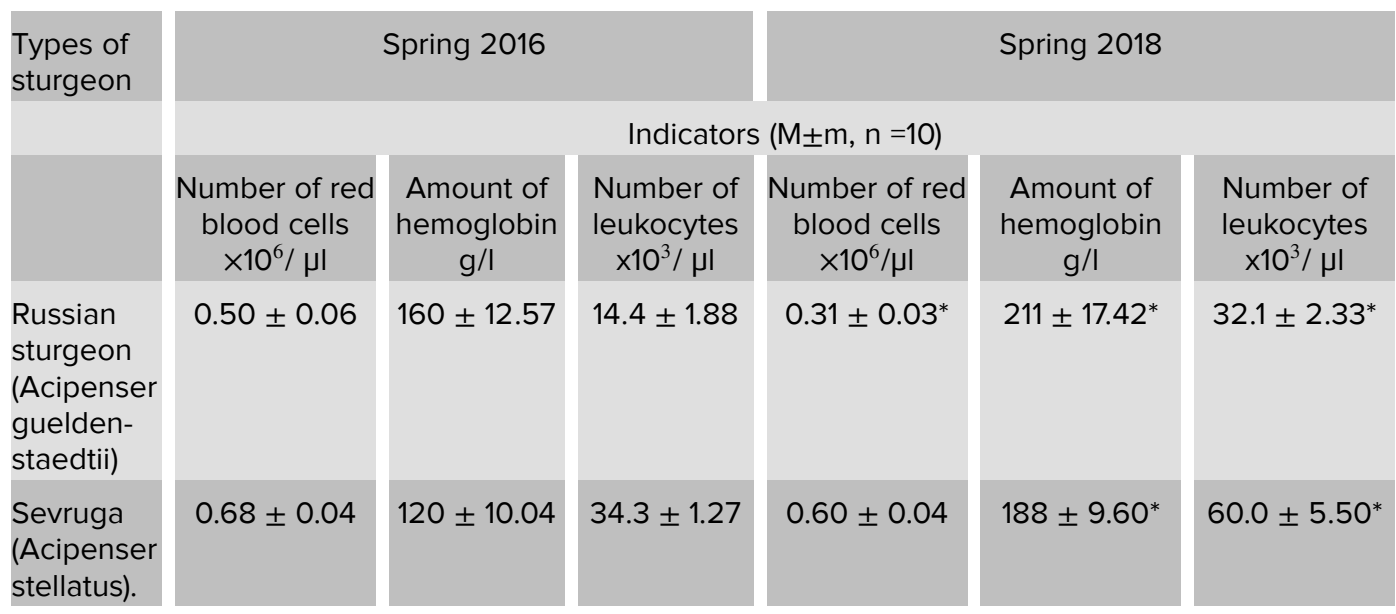

* - reliable difference relative to 2016

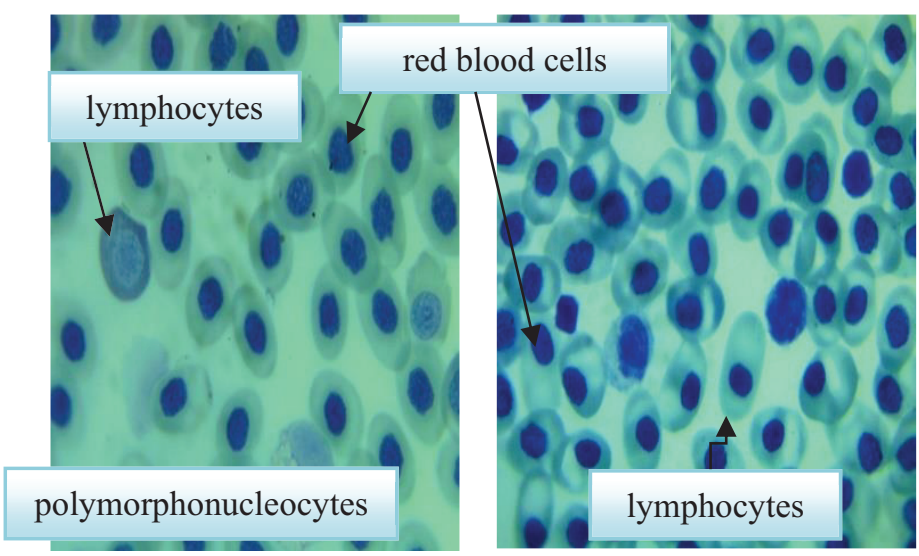

Figure 1: Hemogram of Russian sturgeon (Acipenser gueldenstaedtii) and sevruga (Acipenser stellatus), 2016

literary indicators $\left(15 \times 10^{3} / \mu \mathrm{l}-30 \times 10^{3} / \mu \mathrm{l}\right)$. In sevruga, the same indicator was doubled $\left(34.3 \times 10^{3} / \mu l\right)$ (Table 1).

In the leukocyte formula in the Russian sturgeon lymphocytes occupied $48.5 \%$ of all white blood cells, in sevruga - 53.7\%. It should be noted that the data obtained were reduced compared to the figures given in the literature (70-85\%). Mature lymphocyte cells were rounded, dyed in blue, light blue colors. Lymphocyte nuclei were oval in shape, with blue-violet color. There were broad cytoplasmic lymphocytes, or as they are called, reactive lymphocytes. The nuclei of atypical lymphocytes were rounded, their cytoplasm was larger than in a typical lymphocyte.

The white blood morphology of Acipenser gueldenstaedtii (Russian sturgeon) revealed band and segmentonuclear granulocytes. Band neutrophils accounted for $12 \%$ of all white blood cells. The cells were oval-shaped, with preserved contours. The nuclei were elongated, dyed purple. Neutrophils with segmented nuclei were found 
much more often: Russian sturgeon $-28 \%$, sevruga $-7 \%$. The number of segments was $3-5$, while they were connected by thin links. The segmentonuclear eosinophils were two times less (10\%) in the Russian sturgeon. In percentage terms, their number of sevruga was $4 \%$. The cells were rounded, oval in shape. Sometimes the cell contours were disturbed by the granules outside the cell. The granules were dyed orange, lateritious color.

The leukogram of the Russian sturgeon also revealed small quantities (1.5\%) of band eosinophils - cells of extreme response (Fig. 1). The study of cytomorphology showed that the membrane of eosinophils is destroyed, the nucleus is irregular, elongated, eccentric and dyed purple. The granules of band eosinophils were also dyed bright orange or yellow.
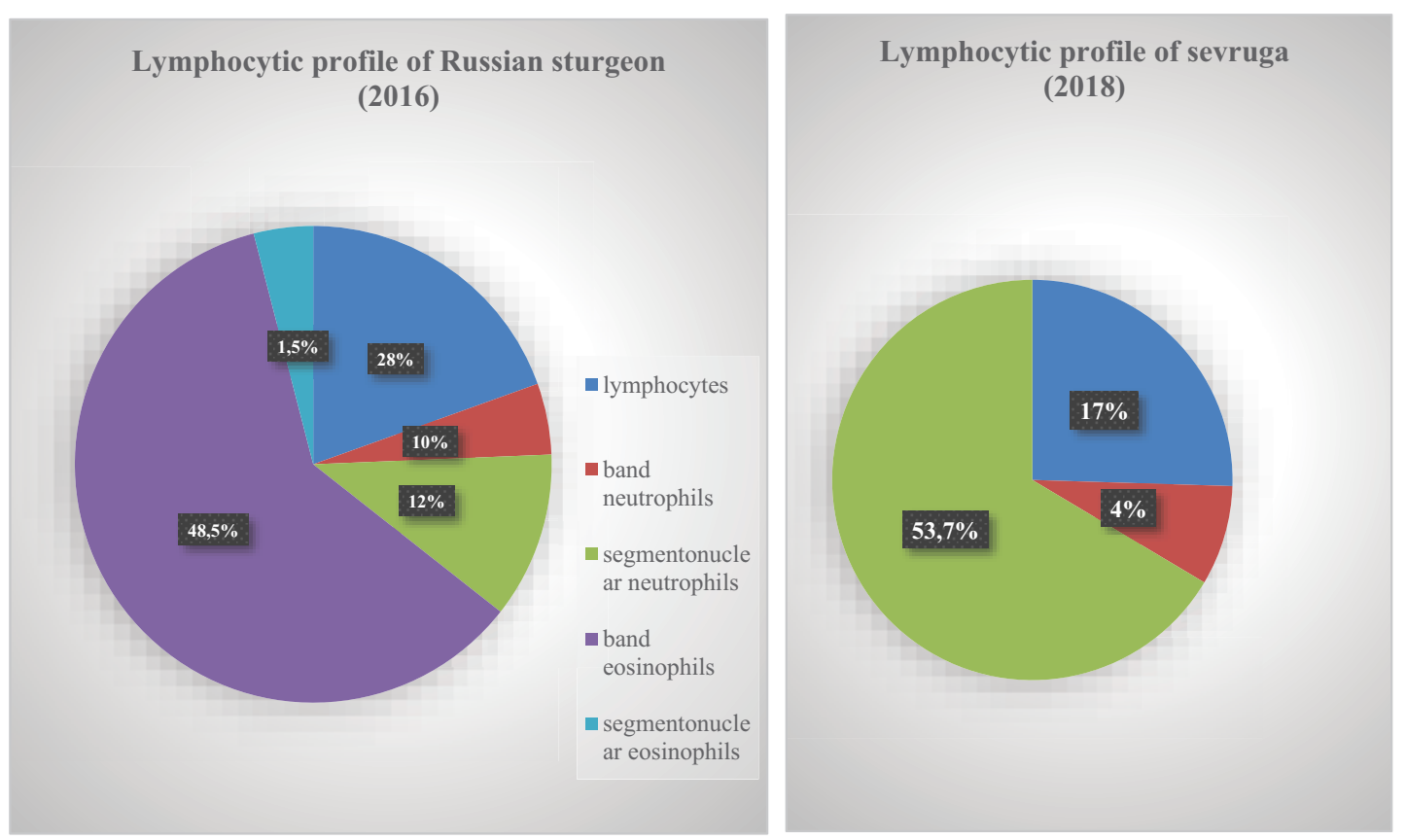

Figure 2: Ratio of different groups of leukocytes in peripheral blood of Russian sturgeon (Acipenser gueldenstaedtii) and sevruga (Acipenser stellatus), 2016

In cytomorphological terms, the destructive disorders were revealed. Such phenomena are associated with the ever-increasing anthropogenic load on the biocenoses of natural reservoirs.

It is interesting to compare the results received in 2016. When studying the red blood of the Russian sturgeon, the proportion of red blood cells was $0.31 \times 10^{6} / \mathrm{\mu l}$. The number of red blood cells in the sturgeon (Acipenser stellatus) was $0.60 \times 10^{6} / \mu \mathrm{l}$. The obtained data are in the range of literary indicators: $0.40 \times 10^{6} / \mu l-0.70 \times 10^{6} / \mu$ l. Sturgeon erythrocytes had an oval shape and distinct cytoplasm contours. Nuclei had a rounded shape, on the preparations were dyed blue. $7-8 \%$ of the red blood cells of the Russian sturgeon 
had pathomorphological changes. Poikilocytosis is especially noteworthy. There were cells of a sickle, elongated and semicircular shape. Perinuclear zones of enlightenment were found in the cytoplasm. Among red blood cell nuclei, the structural disorders were not detected both in Russian sturgeon and in sevruga, with the exception of wall nuclei. Such cells accounted for $2-3 \%$ of all red blood cells. About $5 \%$ of red blood cells were anucleate. Minor changes in the size of red blood cells were observed. Blood cells were visualized at the destruction stage, which can also be attributed to pathomorphological changes (Fig. 2).

In the peripheral blood of the studied species, the hemoglobin content was as follows: in sturgeon - 188g/l, in Russian sturgeon - 211 $/ \mathrm{g}$. The values obtained are higher relative to the conditional norm (83-92 $\mathrm{g} / \mathrm{l})$.

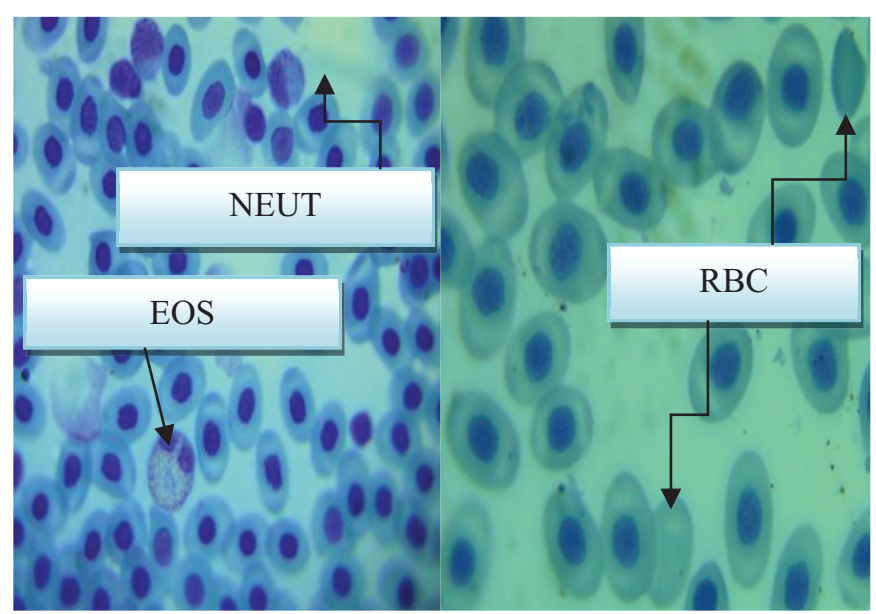

Figure 3: Hemogram of Russian sturgeon (Acipenser gueldenstaedtii) and sevruga (Acipenser stellatus), 2016

In the peripheral blood of sevruga the number of white blood cells $\left(60.0 \times 10^{3} / \mu \mathrm{l}\right)$

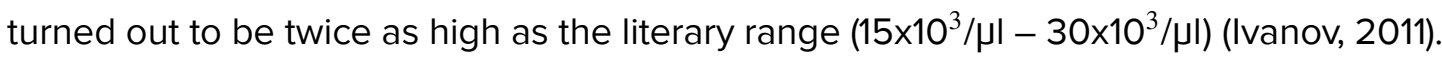
The number of white blood cells in the Russian sturgeon was slightly increased and amounted to $32.1 \times 10^{3} / \mu 1$.

The white blood morphology of the studied sturgeon species was characterized by a slight decrease in lymphocytic profile. Thus, the number of lymphocytes in Russian sturgeon was $55.5 \%$, in sevruga $-58.5 \%$, which is $10-12 \%$ lower than the literary indicators (70-85\%). They had a dark purple round nucleus, in which chromatin formed transitions from denser to less dense areas. In the cytoplasm of lymphocytes, intermittency was observed, sometimes the cytoplasm formed bulges that gave the cell an ameboid shape.

In sevruga, the cells from the granulocyte class were identified. Band neutrophils were found in small amounts $-6.5 \%$. These were cells of rounded, oval, sometimes irregular 
shape. The irregular blue-purple nuclei were eccentrically located. The yellow-orange granules of eosinophilic elements (43\%) were densely located against the background of a weakly azophilic cytoplasm and in some cases overlapped the nucleus. A similar morphological pattern was observed in segmentonuclear granulocytes. In quantitative terms, the percentage of neutrophils was $11 \%$, eosinophils $-25.5 \%$ (Fig. 2).
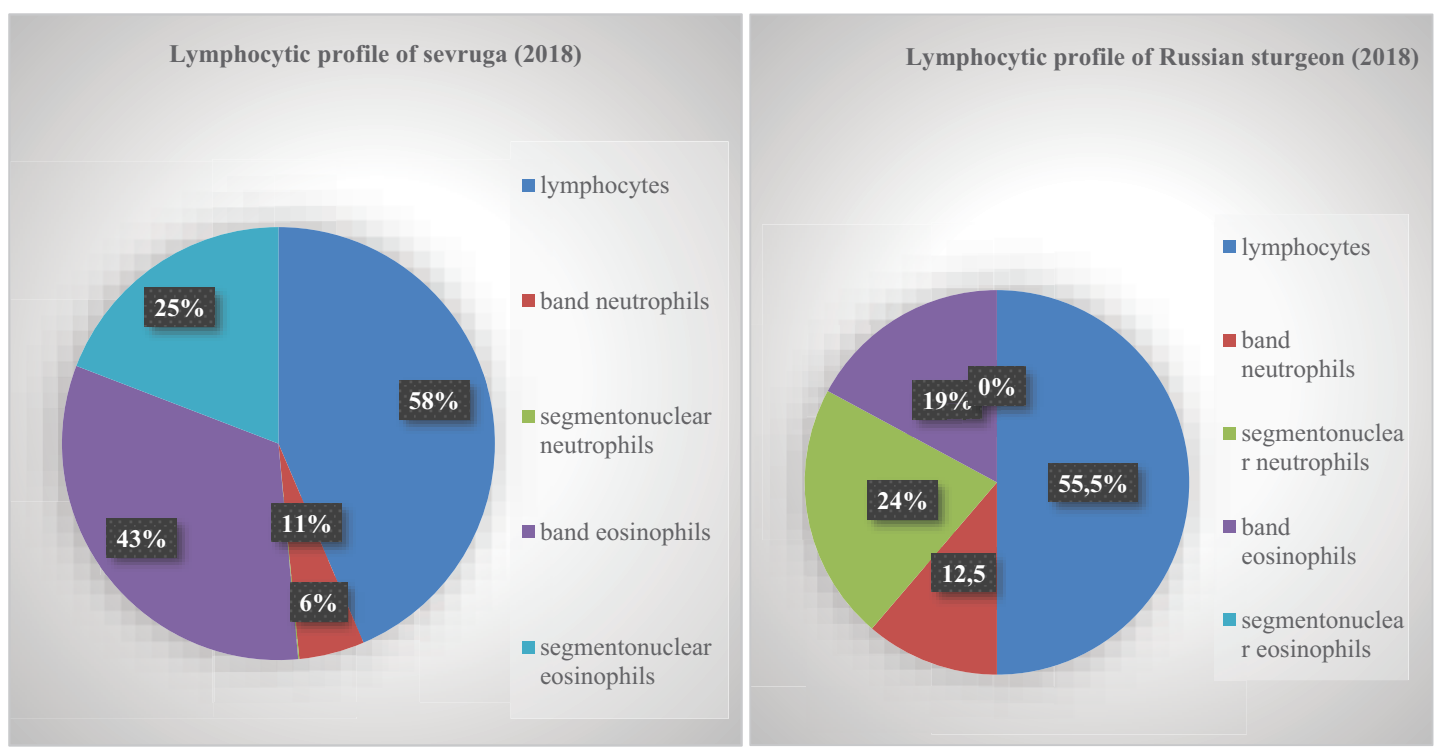

Figure 4: Ratio of different groups of white blood cells in peripheral blood in Russian sturgeon (Acipenser gueldenstaedtii) and sturgeon (Acipenser stellatus), 2018.

Granular cells were also found in Russian sturgeon: band neutrophils (12.5\%), segmentonuclear neutrophils (24\%) and segmentonuclear eosinophils (19\%) (Fig. 2). Band neutrophils were rounded or oval in shape, cell nuclei elongated and decentralized. Segmentonuclear neutrophils had a rounded and irregular shape, nuclei were divided into 2-5 segments and connected to each other by thin filamentous bridges. Basically, the dissected nucleus was located around the cell periphery. Segmentonuclear eosinophilic elements had uneven cytoplasm contours due to orange granules located in the cytoplasm. The cell nuclei were dissected into separate segments, which, in most cases, were located along the cell periphery (Fig. 2).

Thus, summarizing the results, it can be concluded that the quantitative indicators of the red blood in Russian sturgeon (Acipenser gueldenstaedtii) and sevruga (Acipenser stellatus) caught of the Dagestan coast of the Caspian Sea were reduced in the spring period of 2018 compared to 2016 (Table 1), but were in the range of the norm given in literature. The concentration of hemoglobin in Russian sturgeon in 2018 was 13\%, and sevruga - 15\% higher than in 2016. This phenomenon can be considered as a measure compensating the lack of oxygen in various fish tissues and organs. 
The number of white blood cells of Acipenser gueldenstaedtii caught in 2018 was twice as high as the indicators obtained in 2016, but was within normal limits. The amount of white blood in sevruga turned out to be $50 \%$ higher than the data obtained earlier and the figures indicated in the literature.

\section{Conclusion}

The cytomorphological and quantitative blood analysis of Russian sturgeon (Acipenser gueldenstaedtii) and sevruga (Acipenser stellatus) during the period (2016-2018) gives reason to talk about some deterioration in the physiological state of Caspian sturgeons for the period of study. The study of the leukocyte profile of sturgeons showed that the granular forms of leukocytes were found: band neutrophils and eosinophils, as well as segmentonuclear neutrophils and eosinophils. The total number of granulocytes in the blood of Russian sturgeon was increased, which indicates the body's proteciton systems in response to an anthropogenic load. In cytomorphological terms, the destructive disorders were revealed. Such phenomena are associated with the ever-increasing anthropogenic load on the biocenoses of natural reservoirs.

The obtained quantitative indicators of the red blood in Russian sturgeon (Acipenser gueldenstaedtii) and sevruga (Acipenser stellatus) caught of the Dagestan coast of the Caspian Sea were reduced in the spring period of 2018 compared to 2016 (Table 1), but were in the range of the norm given in literature. The concentration of hemoglobin in Russian sturgeon in 2018 was 13\%, and in sevruga - 15\% higher than in 2016. This phenomenon can be considered as a measure compensating the lack of oxygen in various fish tissues and organs.

Summarizing the results, it can be concluded that the pathological changes in the blood cells of physiological processes identified in the studied sturgeon fish in the Caspian Sea cannot but affect the fish-breeding quality and not cause a decrease in their reproducibility.

\section{References}

[1] Abdullaeva, N. M. and Ramazanova, M. G. (2014). Influence of the Aktara Pesticide on the Hemogram of Cyprinid Fish, Zoological Readings. Novosibirsk: NSPU, p. 63-64.

[2] Ramazanova, M. M. and Gabibov, N. M. (2016). Abdullaeva, Analysis of Peripheral Blood of the Russian Sturgeon living in the Middle Caspian Sea. In Ecobiological problems of the Azov-Black Sea region and integrated management of biological 
resources, pp. 238-240.

[3] Guliev, R. A. and Melyakina, E. I. (2014). Some Biochemical Blood Indices of Fish of the Volga Delta. ASTU Bulletin, Series: Fishery, vol. 2, pp. 85-91.

[4] Kalinina, V. N. and Pankin, V. F. (2002). Mathematical Statistics. Moscow: Drofa, p. 336.

[5] Magzanova, D. K., Zhuravleva, G. F. and Egorov, M. L. (2005). Physiological Indicators of Sturgeon Fish Producers in Modern Environmental Conditions. Successes of Modern Natural Science, vol. 8, pp. 14-16.

[6] Pikitch, E. K., et al. (2005). Status, Trends and Management of Sturgeon and Paddlefish Fisheries. Fish and Fisheries, vol. 6, pp. 233-265.

[7] Nguyen, D. F., et al. (2013). Hepatosomatic Index of Sturgeon, Beluga and Sevruga in the River Period of Life. ASTU Bulletin, Series: Fishery, vol. 1, pp. 154-161. 